\title{
The Syntactic and Semantic Analysis of Suffix -in in Balinese
}

\author{
Nyoman Sujaya ${ }^{1}$, I Nyoman Kardana ${ }^{1}$, Ketut Artawa $^{2} \&$ Made Sri Satyawati $^{2}$ \\ ${ }^{1}$ Warmadewa University, Bali, Indonesia \\ ${ }^{2}$ Udayana University, Bali, Indonesia \\ Correspondence: Nyoman Sujaya, University of Warmadewa, Bali-Indonesia. Tel: 628-1338-646-053. E-mail: \\ nyomansujaya753@gmail.com
}

Received: November 14, 2019; Accepted: December 4, 2019; Published: December 9, 2019

\begin{abstract}
This paper discusses the syntactic and semantic analysis of Balinese suffix -in. It is to determine its distribution in sentence construction. This study uses the RRG theory by Van Valin and Randy (1999) supported by the data taken from Balinese articles issued in the Bali Orti of Bali Post newspapers. The result of the analysis shows that as a transitivizing suffix, Balinese suffix -in can be added to nominal, adjectival, adverbial, intransitive and transitive bases. Syntactically, -in can be used in stative, transitive, imperative, passive constructions. The word orders assigned by the suffix -in require different morphology of the verbs. Semantically, the derived verbs with in refer to the activities treating object as static target of action. As an applicative suffix, -in expresses causative, benefactive, source or locative meaning.
\end{abstract}

Keywords: suffix in, syntactic and semantic representation

\section{Introduction}

\subsection{Introduce the Problem}

Balinese language is spoken on the island of Bali, one of the islands in Indonesia, by around 3.3 million speakers, more or less $83 \%$ of population of Bali, which was recorded as 3, 890, and 757 in 2018. According to Artawa (2013), Balinese belongs to Malayo-Polynesian language group. The morphology of the Balinese verb is indeed very simple; it has no tense, no infinitive, and no active participle. However, it has means of distinguishing between active and passive voice. In practice, Balinese people can use it without any ambiguity. Although the units of expression are simple, the use of the verb, in practice, is very complex, because its morphology involves the modification of affixes including the modification by the attachment of -ang or -in to the end of the verb or leaving it unsuffixed. This condition brings various meanings: e.g. tutur 'story', nutur 'to have a chat', tutur-ang 'be told to a person', nutur-ang '(someone) tells about (things, events)', nuturin '(someone) tells a person something.

\subsection{Importance of the Problem}

The focus of this study is about the syntactic and semantic analysis of suffix -in. The goal of this paper is to determine the distribution of suffix -in verbs in Balinese sentence constructions. It uses data from narratives and conversational texts of Bali Orti pages of the Bali Post newspaper issued in the year 2017, 2018, and 2019. It also uses informants to support the data. For the analysis, the writer used the notion of morphosyntactic structure that the writer quoted from Van Valin and Randy (1999), stating that it is necessary to look at morphosyntax if we are to capture linguistic regularities, not just syntax or morphology.

This research is organized in three sections. Section one talks about the introduction which covers the reasoning of choosing the topic. In two it is discussed about the derivational morphology of Balinese verbs forms, the main discussion is in section three, and the last section is about the conclusion of this study.

First section is about the introduction which covers the reason of choosing the topic. The second section discusses about the derivational morphology of Balinese verbs forms. The third section is considered as the main section; and the last section is the conclusion of the study.

\subsection{Relevant Scholarship}

It is true that in recent years, a number of scholars have discussed about Balinese verbs including the derived ones. Arka (2005), for example, discussed about speech levels, social predicates and pragmatic structure in Balinese, Indrawati (2011) examined about Balinese serial verbs construction, Artawa (2013) talked about the basic verb constructions of Balinese, Kardana (2014) studied about Morphosyntax of Balinese Reciprocal Constructions. 
Bagus (2018) did a research on Intransitive verb makers in Balinese, and Eka (2018) wrote about On The Situated Socio Cultural Meaning Of Benefactives In Balinese.

Those researchers mentioned above have talked about syntactic analysis which theoretically cannot be separated from semantic perspective. They explained how the morphosyntax works. They have discussed about the grammar of a certain unit of language. However, they have not discussed about a certain type of Balinese affix in detail. They haven't talked about the applicative suffix -in. They haven't studied how the suffix -in works morphosyntactically, so that, to me, a serious study on it is necessary to be conducted. .

Basically this research applied the RRG theory proposed by Van Valin and Randy (1999). Other theories of Balinese grammar from Barber (1978), Kersten (1984), and Thomas Marshall Jr. (1988), are also adopted for the analysis of this research. The RRG theory states that analyzing the communicative function of grammatical structures plays important role in grammatical description. RRG does not only concern with syntactic structure but also with semantic and pragmatic relations.

Since this reach is aimed at analyzing the syntactic and semantic relation, which involves morphosyntax of verb forms, before the discussion it is necessary to explain about Balinese morphology, namely derivational morphology which involves unmarked form and affixation.

In Balinese, stative and intransitive verbs occur either in the form of unmarked base or verbs with prefix ma-. Balinese stative and intransitive can be characterized into non-volitional stative and intransitives, verbs of motion and related intransitives, and specialized stative-intransitive verbs. These can be seen in the figure below.

Table 1. Non-volitional stative and intransitives

\begin{tabular}{lll}
\hline $\mathrm{L}$ & $\mathrm{H}$ & Meaning \\
\hline takut & ajerih & be afraid \\
inget & éling & remember \\
kedék & ica & lough \\
tawang & uning & know \\
pules & sirep & sleep \\
\hline
\end{tabular}

Table 2. Verbs of motion and related intransitives

\begin{tabular}{lll}
\hline $\mathrm{L}$ & $\mathrm{H}$ & Meaning \\
\hline teka & rauh & come \\
luas & lunga & go out \\
mulih & mantuk, budal & come home \\
pesu & medal & appear \\
milu & ngiring & join \\
\hline
\end{tabular}

Specialized stative-intransitive verbs

a. Existential (there is/are) ada $(\mathrm{L})$ wénten $(\mathrm{H})$

b. 'happen, become' (by extension: be permitted to): $\operatorname{dadi}(\mathrm{L}) \operatorname{dados}(\mathrm{H})$

When there is a volitional component involved in an activity, or it is a transitory state that is being described, the $m a$ - form is used as the transitive verbs, like the examples below.

Table 3. Stative forms with $m a$ - added to nouns

\begin{tabular}{lll}
\hline $\mathrm{L}$ & $\mathrm{H}$ & Meaning \\
\hline ma-adan & ma-wasta/ma-parab & be named \\
ma-tuuh & ma-yusa & be of the age \\
ma-isi & ma-daging & contain \\
ma-bulu & uning & have feathers \\
ma-sebeng & sirep & have pained expression \\
\hline
\end{tabular}


Table 4. Intransitive verbs taking $m a$ -

\begin{tabular}{lll}
\hline ma-lajah & & study \\
ma-lali & ma-lancar-an & take trip \\
ma-balih & ma-cingak & watch \\
ma-celep & & enter \\
ma-keneh & ma-manah & think \\
\hline
\end{tabular}

$m a$ - stative with 'passive' interpretation

In this section it is explained that prefix ma- expresses patient argument, it is a passive interpretation. According to Kersten (1984) it is a passive transitive interpretation with ma-. If a base word is transitive the derived form often ha a passive meaning. Josep (Thomas, 1988, 188) states that ma- used with some bases indicates passive idea, but in this case agents play reduced role. In this construction the agent is not considered to be important.

Examples.

Umah-é suba m-adep

House-DEF accomp. Sta-sell

'The house is already sold'

Siap-é jani ma-kurung

Chicken-DEF now sta-pen

'The chicken has been penned up'

Prefix $p a$ - as nominalizer

$p a(n g)$ - is used to form derivation of nouns that are oriented towards

Actor arguments, especially agents or instruments.

I pa- + base or pang- + base:

a. Instrumental and agentive nouns

1. pang-asih 'potion for love magic'

2. pang-ijeng 'watchman'

b. habitual actor nominal

1. pa-takut (panakut) 'coward'

2. pa-beler (pameler) 'prankster'

c. abstract nouns

1. pangrauh 'arrival'

2. pakéling 'reminder'

II pa- + base + -an or pang- + base + -an

a. locative nouns (where action is performed)

1. pa-saré-an 'bed'

2. pang-urit-an 'place to germinate rice'

b. abstract nouns with temporal mening.

1. pa-bakti-an 'day of worship'

2. pa-nampah-an 'day before ritual for slaughtering animals'

Balinese nominal taking $p a$ - can also have reference to arguments with the semantic relation of patient to the action. In this case it has the same motivation with passive meaning of $m a$ - for transactional verbs like 'sell'. In this case $p a$ - is used in transactional activities like 'give' and 'borrow' (Thomas, 1988: 193).

Examples.

1. pa-silih 'things borrowed'

2. pa-kidih 'things asked for' 
Suffix -an in Balinese

In Balinese, $-a n$ is used to form nominal goal. The derivation that can be formed by suffix $-a n$ can be base $+-a n$ form like the examples below.
1. dum-an 'portion'
2. alap-an 'things plucked'
3. ajeng-an 'food, rice' (ready for eating)

$-a n$ is also used to form specialized non-volitional verbs that is expressed by $k e-+$ base $+-a n$ in Indonesian language.

Examples:

1. ujan-an 'caught in the rain'

2. peteng-an 'caught out in the dark'

Reduplicated forms taking - an can also form derived nouns from nominal bases. The derived forms refer to the plural or distributive aspect of the nominal base like the examples below.

1. togog-togog-an 'all kinds of statues'

2. mas-mas-an 'all kinds of jewelry and ornaments made from gold'

There are also $m a-+$ base $+-a n$ verb forms in Balinese which refer to (a) actions carried out reciprocally, or (b) the ongoing or continuous activity.

(a) Reciprocal actions:

\section{Anak cenik nto ma-timpug-an}

Person little Det sta-throw stones-LF

'Those little kids were throwing stones at each other'.

(b) Ongoing or continuous quality of event

\section{Lantas ma-paitung-an ajaka dadua}

Then sta-counsel-GF the two together.

'Then the two of them took counsel together'

-an can also be used to form the comparative grade. In this case - $a$ is usually added to adjectives and adverbs.
1. luung-an 'better'
2. gelis-an 'faster'
3. dini-an 'closer to here'
4. ditu-an 'closer to there'

Reduplicated forms with -an can be used to indicate the excessive or superlative degree of a quality.

1. gelis-gelis-an 'as fast as possible'

2. adéng-adéng-an 'as slow as possible'

Actor focus construction

In Balinese, actor focus is identified by prefix $N$ - (Nasal). $N$ - covers many types of actions, some volitional, others not, some transitive and directed towards objects, some intransitive, and representing self-contained actions. There are three main types of $\mathrm{N}-+$ base derivation, depending on the semantic types of the modified base:

(1) Based on the nominal bases: in this case there is usually metaphorical or metonymous relationship between the nominal base and the activity specified by the verbal derivation formed with $\mathrm{N}$ -

$k u b u$ 'shack in the rice-fields' $\rightarrow n g u b u$ 'live in a shack in the rice-fields'.

$k o p i$ 'coffee' $\rightarrow$ ngopi 'drink kopi'.

(2) Those based on intransitive verbal bases: some intransitive bases require N- + base, while others have both unaffixed and $\mathrm{N}-+$ base forms. The unaffixed forms refers to more punctual or discrete events. ngoyong 'to live, reside somewhere' 
ningeh 'listen, hear'.

(3) Those based on transitive verbal bases (or nominal bases that have a transitive element when transposed into the verbal system): $N-+$ base constructions formed on these base can take simple patient arguments. ngaé bangbang 'make a hole' ngadep nasi 'sell rice'

Balinese transitivizing suffixes

There are actually two suffixes functioning as transitivizer, they are suffix -ang and -in. This part only discusses about the suffix -ang, the later, since it is about the topic of this study, will be discussed at the other section, that is in part III. As a transitivizer, -ang can be added to nominal, adjectival, adverbial, intransitive, and transitive bases.

Examples:

1. Nominal base: sentana 'heir' --_nyentanaang 'to take an heir'

2. Adjectival base: tegeh 'high' -- negehang 'to make something high'

3. Adverbial base: kelod 'North' -- ngelodang 'move something to the North'

4. Intransitive base: malaib 'run' -- malaibang 'take something away'

5. Transitive base: meli buy' -- meliang 'buy something for someone else'

Causative constructions by prefix $p a$ - in Balinese

There are some constructions that can be made with prefix $p a$ - to express causative meaning. In verbal constructions prefix pa is used to form causative stems in which the $p a$ - element can be said to make reference to mediate Actor participants. These stems can be in unsuffixed or suffixed form and can be used in both Actor focus or passive constructions (Thomas, 1988: 2007). The $p a$-constructions can be seen in the following examples.

a. $\quad p a-+$ base forming derived transitive from stative bases.

takut 'afraid' $\rightarrow$ pa-takut 'to frighten'

éling 'remember' $\rightarrow$ pa-kéling 'to remind'

b. $\quad p a-+$ base + -ang forming derived transitive from intransitive or nominal bases.

laib 'run' $\rightarrow$ pa-laib-ang 'runoff with'

besen 'message' $\rightarrow$ pa-besen-ang 'give a message'

c. $\quad p a-+$ base + -ang forming morphological causatives from transitive bases.

suun 'carry on the head' $\rightarrow$ pa-suun-ang 'have place on the head'

gelut 'hug' $\rightarrow$ pa-gelut-ang $\rightarrow$ 'make to hug'

d. $p a-+$ base $+-i n$ forming derive transitives from adjectival bases concerned with extension, speed, intensity, and the like.

tegeh 'high' $\rightarrow$ pa-tegeh-in 'make higher'

becat 'fast' $\rightarrow$ pa-becat-in 'make faster'

$K a$-passive forms

In Balinese, the $k a$ - passive forms show the morphosyntactic variation and they carry a number of different meanings. There are five types of $k a$ - passive form; $k a$ - base form, $k a$ - base -ang form, $k a$ - base -in form, and $k a$ base - an form.

1. $k a$ - base form: ka-icén 'was given'

2. $\quad k a$ - base -ang form: $k a$-silur-ang 'was changed'

3. $k a$ - base -in form, ka-panggih-in 'was found'

4. $\quad k a$ - base -an form ka-tinggal-an 'was left'

In $k a$ - passive form, the agent, if mentioned, is marked by preposition teken, baan (low register), and antuk, or ring (high register) 'by'.

Canang-é puniki sami ka-karia-nin antuk panak tiang-é sané paling alit

Offering-DEF this all PASS-make-APPL by child 1SG-POSS that most small 
'All the offering were made by my youngest doughter'.

\section{Method}

This study uses the RRG theory by Van Valin and Randy (1999) supported by the data taken from Balinese articles issued in the Bali Orti of Bali Post newspapers. The reason of choosing these articles was that these articles contained various forms of narrative texts including conversational ones so that they were considered naturally used. The analysis was done through a descriptive method (syntactically and semantically how the morphosyntax worked in relation to suffix -in constructions). The result of the analysis shows that as a transitivizer, Balinese suffix -in can be added to nominal, adjectival, adverbial, intransitive and transitive bases. Syntactically, -in can be used in stative, transitive, imperative, passive constructions. The word orders assigned by the suffix -in require different morphology of the verbs. Semantically, the derived verbs with -in refer to the activities treating object as static target of action. As an applicative suffix, -in expresses causative, benefactive, source or locative meaning.

\section{Results}

In Balinese, suffix -in functions as a transitivizer. It implies that the object is 'immobile' or locative in nature (Thomas, 1988: 201). It is considered the same with the use of suffix $-i$ in Indonesian but quite different from the use of Balinese suffix -ang in which with -ang the object is mobile. A verb with -in refers that the object is treated as static target of action. As a transitivizer, suffix -in can be added to some bases. It can be added to adjective, noun, verb, or even adverbial of direction. The addition of suffix -in to the base varies in meanings.

\subsection{Stative Verbs with Suffix -in}

If added to adjective meaning feeling, sadness, etc, suffix -in mostly expresses the meaning of 'making or arising feeling sadness on the object. The derived words are always in nasal form (Kersten, 1984: 64). Syntactically, the suffix -in added to adjective base forms stative intransitive construction like in the following data.

a. Suud Ng-inem kéto, nto nak N-punyah-in

Finish Ng-drink that, that can Intrans.-drunk-APPL

'Stop drinking such kind of drink, it makes you drunk'

b. Dadaaran-né mula jaan kuala énggal Ng-emed-in

Food-DET indeed delicious but soon Intrans.bored-APPL

'The food was indeed nice but it soon made me bored'

The data above shows that in a, the verb munyahin is formed from the adjective base punyah 'drunk' attached with prefix $N$ - combined with suffix -in to form stative intransitive sentence. -in in this context implies causative meaning. The stative verb ngemedin in b is also formed from the adjective base emed 'bored' and -in in this case also expresses causative meaning.

\subsection{Suffix -in in Transitive Construction}

As a transitivizer, suffix -in can be added to nominal, adjectival, adverbial, intransitive and transitive bases. The derivational forms bring various constructions and meaning. Each construction will be discussed in the following.

\subsubsection{Suffix -in Added to Nominal Base}

The noun added with suffix -in can form a transitive verb implying the meaning of giving noun denoted by the noun base. In some cases, the derived verbs with -in from the noun base may express doing something for someone else, -in expressing benefactive meaning, in other cases -in may express locative meaning (Kersten, 1984: 67).

Examples:

a. "Nah, lamun kéto kanggoang Aji mekel-in satu juta

"Ok, if like that let $1 \mathrm{SG}$ Trans.give one million

dogén pipis ané ada jumah”. (Bali Post, 7/1/18)

Only money that there house

'If it is like that, just let me give you one million only that I have at home'

b. Suba lebeng bagusanga Ng-wadah-in kau padaaran bapanné pajanga di dlang padaaran bapanné tekepina, kéwla Luh Sari sing ja bani nyicipin, bas sakala taén siap (30/6/19)

Suffix -in in data a above expresses the benefactive meaning, in this construction it is the addressee is being the benefactee. In data $b$ above, suffix -in is used to express different meaning, in this case it is used to express locative 
meaning.

Suffix -in may also express the meaning of 'making something produce something' like the example below.

Ia N-bunga-in pipis-é ané silih-a ajak timpal-né

3SG Trans-interest-APPL money-DEF that borrow-3SG friend-POSS

She took interest from the money lent to her friend'

In other cases, according to Hunter (1988), there is also locative like feature of suffix -in added to noun like in the following data.

I Ketut lakar masang-in céléng

Art Ketut future Trans.-stomach-APPL pig

'Ketut is going to take out the stomach of the pig'

Mémé N-kulit-in biu anggon-a panak-né

Mother Trans.-skin-APPL banana use-PASS child-POSS

'Mother is peeling the banana for her child'

\subsection{2 -in Attached to Adjectival Base}

If added to adjective meaning feeling, sadness, etc, suffix -in mostly expresses the meaning of 'making or arising feeling, sadness on the object'. The derived words are always in nasal form. (Kersten, 1984: 64).

Examples:

a. Moné baan-a N-jengah-in bapa, yén sing mati baan bapa

This much with-3SG Trans.-anger-APPL father, if not dead by father

N-daya-ang sing lega-lega nyet bapa-né (Bali Post, 18/8/19)

Trans.-do-APPL not happy mind father-POSS

'It's that much he did something bad to me, if I fail to kill him I will never feel satisfied'

b. Patung ageng sané kakaryanin saking ulatan tiing

Statue big that PASS-make-APPL from woven bamboo

puniki nénten wantah becik, nanging taler $\mathbf{N}$-ulangun-in

this not only good, but also Trans.-satisfy-APPL

manah (Bali Post, 9/6/19)

mind

\subsection{3 -in Attached to Adverbial Base}

Suffix -in added to adverbial base can form a verb that expresses adverbial meaning, a verb that expresses how something is done. This is illustrated in the following data.

a. Ia N-adéng-in ma-jalan mara $\mathrm{N}$-tepuk-in kuluk galak

3SG Trans.-slow-APPL Intrans.way just Trans.-see-APPL dog wild

'He slowed down his walk while seeing a wild dog'

b. Wénten iring-iringan krama ka-ungkur-in gong blaganjur

There march of people PASS-back-APPL music blaganjur

lan panyatusan para pangiring (Bali Post, 14/7/19)

and hundred those followers

'There was a march of people followed with Balinese traditional music and a hundred of followers'

\subsection{4 -in Modifying Intransitive Verb}

According to Thomas (1988: 201), when -in is used to form derived transitive from intransitive bases, it is different from those derived from - ang in terms of the dynamicity of the patient. Suffix -ang is used when the object is mobile while suffix -in is used when the object is 'immobile' or 'locative in nature'. In this case -in refers to objects treated as static target of action. 
a. Maka dadua nyak pada adung Ng-ayah-in ia, sawiréh suba

Both Two able same cooperative AF-serve-OF 3SG because already

ka-pituduh-ang olih reraman-né apang prasida ngelah sentana

PASS-oblige-OF by father-POSS in order able have child

(Bali Post, 14/1/18)

'Both of the women cooperatively served him since they were required by their parents so in order that they can have children'.

b. Ia ma-laib-in lawat-né padidi.

3T Trans.-run-APPL shadow-POSS

'He ran away from his own shadow'

In data a above, it can be seen that suffix -in is used to express benefactive meaning, while in $\mathrm{b}$-in is used to express source.

3.2.5 -in Modifying Transitive Verb

When attached to transitive verb, the suffix -in replaces the preposition like in the following data.

Ipun nunas jinah ring I Guru ipun

3SG beg for money from I Guru

'He begged for money from I Guru'

Ipun nunas-in I Guru jinah

3SG begged for-APPL I Guru money

'He begged for money from IGUru'.

The addition of -in to the transitive base often changes the valence of the clause. It increases from mono-transitive clause into di-transitive. This can be seen in the following data.

a. Tiang N-beli tanah

1SG Trans.-buy land

'I bought land'

b. Tiang N-beli-nin ia tanah

1SG buy-APPL 3SG land

'I bought land from him'

c. *Tiang meli ia tanah

1SG buy 3SG land

'I bought land from him'

However, -in some cases, not all of the arguments of the di-transitive verbs or the 'giving' verbs are explicitly mentioned in the construction as can be seen in the following data.

a. Pasaruang tiang lakar N-beli-in dagangan-né (Bali Post, 4/3/18)

Pretending 1SG will Trans.-buy-APPL goods -POSS

I pretended to buy goods from her'

b. Ni luh Sari bareng Bapané nglek ati ngorahang N-pumpun-in

Art girl Sari and father-POSS shy heart saying Trans.-give-APPL

bungkil tiing (18/8/19).

'Luh Sari and her father were shy to say that they gave bamboo root'

\subsection{Suffix -in in Imperative Construction}

The only grammatical mark of the Balinese imperative is the suffix -ang, which is often added to the base-form without changing its meaning. The verb may be base-form or N-form. These verbs may have no suffix or have ang or -in. Those with in can be seen in the following data. 
a. Yén koangan pipis, Beli-né malu idih-in.(Bali Post, 7/1/18)

If lack of money, brother-POSS beg for-APPL

'If your money is not enough, you can have it from your brother first'.

b. Yén bapa kondén teka cening malu ngenjuhin

If father not yet arrive 2SG first Trans.-give-APPL

di-né pipis

younger-POSS money

'I I have not arrived yet, you give your younger brother fist'

The negative imperative is made by prefixing $d a, \mathrm{H}$ sampunang 'Don't'. Da- and sampunang are also used with third person verbs to make negative command.

a. Sampunang ma-linggih irika, wenten semut makéh

Don't Intrans.sit there, there are ants many

'Don't sit over there, there are many ants'

b. Da makejang abana, baat gati

Don't all carry-3SG heavy very

'Don't carry them all, they are very heavy'

\subsection{Suffix -in in Passive Construction IN}

In passive construction, suffix -in is added to either the base form or $k a$-form. If the passive verb is in base form, the agent is a pronoun in the first or second person though sometimes expressed with a noun. This construction is identical with that of unmodified S-form verb.

a. Icang katiman lua, kimud icang $\mathrm{N}$-not semitan

1SG although male, embarrassed 1SG Trans.see face

timpa-timpal cainé ané tutur-in cai (Bali Post, 26/5/19)

friends 2SG that PASS.tell-APPL 2SG

'Even though I am a woman I still feel embarrassed to see your friends' faces that you are talking to'.

b. Iba pahica-in kai N-kgodag-ang gumi linggah.

1SG gift-APPL 1SG Trans.-rule-APPL land wide

'You are required (by me) to rule a wide land'

In the base form with -in construction the subject is put after the verb like in the following data.

a. Inem-in-a yéh iba-né lantas $\mathrm{N}$-selélég ia di korsi-né

PASS.drink.-APLL-3SG water self-DEF then Trans.-lean 3SG on chair-DEF

'He drank water by himself then he leant on the chair'

b. Embus-in-a koné kamen-né tur entungang-a di natah-é.

PASS.take off-APPL-3SG said cloth-POSS and throw-3SG on yard-DEF

'It was said she took off her cloth and threw it on the yard'

When the verb is in the $k a$-form, normally no agent is thought of. However, the $k a$-forms with -in quite frequently have an agent, normally expressed with the prepositional phrases with $\mathrm{L}$ tekén, or baan. $\mathrm{H}$ antuk or ring 'by'. The order is $\mathrm{N} 2+\mathrm{Vp}(k a-$-in) + prep.N1 or N3 + Vp $(k a-$-in) $+\mathrm{N} 2$ (in active sentences, N1 stands for the subject, N2 for the patient or the direct object, and $\mathrm{N} 3$ for the second object).

Examples:

a. Nah kéto pasaut-né Ni Celepuk sané raris

Ok that answer-POSS Ni Celepuk who then

Ka-kaonin antuk I Memedi-né (Bali Post, 3/11/19) 
PASS-leave-APPL by I Memedi-DEF

'Ni Celepuk said "ok" then he was left by I Memedi'

b. Okan ipun ka-parab-in Danan Jaya

Child 3SG PASS-name-APPL Danan Jaya

'His son is named Danan Jaya'

When a verb with -in is used in the $k a$ - form, the subject is N3, N2 can be put after the verb, depending on the speaker's choices.

Wénten iring-iringan krama istri nyuun upakara

There is march people woman carry on head offering

Ka-kawit-in anak lanang makta sundih (Bali Post, 14/7/19)

PASS-begin-APPL person male carry lamp

'There was a march of women carrying offering on their heads preceded by a man carrying a light'

\section{Discussion}

This paper has discussed about the syntactic and semantic analysis of suffix -in. It has shown how the morphosyntax works in the constructions with suffix -in. Syntactically, the Balinese suffix -in can occur in the stative verb construction, transitive construction, imperative construction, and passive construction. In general, suffix -in is used to increase sentence valence; from intransitive form to mono-transitive, from mono-transitive to di-transitive. In transitive construction, suffix -in can be added to nominal base, adjectival base, adverbial base, intransitive base, and transitive base. In the imperative forms, in can be added to the base form or nasal form, while in passive construction - in is added to the base form or $k a$ - form. Semantically, as a transitivizer, suffix -in implies that the object is immobile or locative in nature. The derived verbs from intransitive bases taking -in refer that the object is as static target of action. When used applicatively, suffix -in may express causative, benefactive, source or locative meaning.

\section{Acknowledgements}

In this opportunity I would like to thank Jro Mangku Alit (the priest of Balinese family temple), Nyoman Juana (the head of Abian Kapas traditional village), Dewa Putu Sumantra (the expert of Balinese and Indonesian language), Ketut Subagia (a linguist), and other Balinese friends for being informants and giving information during conducting this study.

\section{References}

Arka, I Wayan. (1998). From Morphosyntax to Pragmatics in Balinese: A Lexical Functional Grammar. Sydney: University of Sydney.

Artawa, K. (2013). The Basic Verb Construction in Balinese. Jakarta: NUSA Vol. 54. The Center for Language and Culture Studies Atma Jaya University.

Barber C. C. (1977). A Grammar of the Balinese Language (Vol. 1 \& 2) Aberden University Library, Occasional Publication No.3.

Dixon, R. M. W. (1999a). Semantic Approach to English Grammar. Oxford: Oxford University Press.

Foley, W. A., \& Van Valin Jr, Robert D. (1984). Functional Syntax and Universal Grammar. Cambridge: Cambridge University press.

Kersten J. S. V. D. (1984). Bahasa Bali. Flores, Ende: Nusa Indah, Jl. Katedral 5.

Mas Indrawati, Ni Luh Ketut. (2011). Konstruksi Verba Beeruntun Bahasa Bali (Kajian Semantik dan Sintaksis). Denpasar: Program Pascasarjana Universitas Udayana.

Quirk, et al. (1985). A Comprehensive Grammar of The English Language. New York: Longman Group Limited.

Sedeng, I. N. (2007). Morfosintasksis Bahasa Bali Dialek Sembiran. Analisis Tatabahasa Peran dan Acuan (diseertasi). Denpasar: Program Pascasarjana Universitas Udayana.

Suryati, N. M.. (1997). Verba Berkomplemen dalam Bahasa Bali. (tesis). Program Pascasarjana Universitas Padjajaran Bandung.

Thomas Marchall, Hunter, Jr., (1988). Balinese Language Eitorical Background and Contemporary. The University of Michigan, U. M. I. 
Van Valin, Robert, D. Jr., \& Lapola, R. J. (1999). Syntax structure, meaning and function. Cambridge: University Press.

Artawa, K. (1994). Ergativity and Balinese Syntax. Disertasi S3 untuk La Trobe University, Australia.

Nyoman Sujaya was born in Singaraja, Bali, Indonesia. He is one of the lecturers at the English Department, Faculty of Letters, Warmadewa University, Bali, Indonesia. He obtained his master degree in linguistics from Udayana University, Bali, Indonesia in 2003. He is currently a doctorate candidate in linguistics majoring on syntax at Udayana University and his main research focuses on Balinese "Giving" Verb Constructions.

I Nyoman Kardana is a professor in Linguistics at Warmadewa University, Bali Indonesia. He got his Master Degree in Linguistics from Padjadjaran University, Bandung, Indonesia in 1998. He obtained his Doctorate Degree in Linguistics from Udayana University, Bali, Indonesia in 2004. His research interest involves a lot of topics about syntax and semantics and he has supervised many papers, theses and doctorate dissertations. He has also written a lot of articles and books and has participated in a number of national and international seminars.

Ketut Artawa is a professor in Linguistics at Udayana University, Bali, Indonesia. He received his Master Degree in Linguistics from La Trobe University in 1992 and got his Doctorate also from La Trobe University in 1995. His research interest involves a wide range of topics about syntax and he has supervised many theses and doctorate dissertations. Up till now he has written a lot of books and articles and has participated in a number of national and international seminars and conferences.

Made Sri Satyawati is a lecturer at Udayana University, Bali, Indonesia. She obtained her Master Degree in Linguistics from Padjadjaran University, Bandung, Indonesia in 1999 and she got her Doctorate Degree in Linguistics from Udayana University in 2010. Her research interest is linguistics, namely syntax and semantics. Her publications involve study on local languages in Indonesia. She has supervised many theses and doctorate dissertations and has participated in a number of national and international seminars.

\section{Copyrights}

Copyright for this article is retained by the author(s), with first publication rights granted to the journal.

This is an open-access article distributed under the terms and conditions of the Creative Commons Attribution license (http://creativecommons.org/licenses/by/4.0/). 